УДК $1 ; 316.6$

DOI https://doi.org/10.32837/apfs.v0i29.960

В. А. Шеховиова-Бурянова

ORCID ID: https://orcid.org/0000-0002-4227-2253

аспірантка кафедри філософії та міжнародної комунікаиї

Національного університету біоресурсів і природокористування України

\title{
ОСОБЛИВОСТІ РЕГІОНАЛЬНОЇ ІДЕНТИЧНОСТІ УКРАЇНЦІВ
}

Постановка проблеми. Регіональну ідентичність часто розглядають у контексті соціальної ідентичності, адже регіональна ідентичність входить в усі сфери людського буття. Регіональна ідентифікація виступає процесом регіональних стратегій розвитку та механізмів місцевого політичного управління, формуючи ідентичність населення.

Регіональна ідентифікація виступає процесом для вибору стратегій регіонального розвитку і механізмів політичного управління на території. Місцевість стає важливою у випадку, коли закінчується життєве середовище та настає екзистенційна аксіологія. У даному випадку даної трансформації створюється певна особливість менталітету та структура специфіки поведінки.

Аналіз останніх досліджень i публікацій. Проблематика регіональної ідентичності розглядається у працях українських науковців Л. Нагорної, О. Картунова, С. Кисельова, А. Колодія, І. Кресіної, В. Лісового, Г. Палій, О. Майбороди, Ю. Саєнка, Ю. Римаренка, Т. Рудницької, М. Шульги та інших.

Мета статті - дослідити особливості регіональної ідентичності українців.

Виклад основного матеріалу. Кожна нація має власну національну ідентичність та менталітет, але водночас може прослідковуватися відмінність у ідентичності, а саме в регіональній ідентичності. Адже на формування ідентичності впливає територіальна місцевість. Регіональна ідентичність виявляється конструктором, тобто формує світогляд та ідентичність певного територіального населення. Апеляція до регіональної ідентичності, як і до будь-якої іншої, може слугувати як засобом прояснення співвідношення політичних сил, так і інструментом політичної боротьби й маніпулювання масовою свідомістю [8, с. 120].

Рівень регіональної ідентичності визначається складним переплетінням історичних особливостей освоєння регіонального простору, характеру етнічного розселення, ступеня урбанізованості території та збереження комплексів традиційної культури. Локальна самосвідомість виникає на грунті рефлексій історичної пам'яті, сполучених з усвідомленням осібності і специфічності регіонального простору як середовища життя обмеженої територіальними рамками спільноти [8, с. 81].
Серед механізмів, що залучаються для цільового формування регіональної ідентичності, можна виділити такі: використання механізму конструювання кризової або опозиційної регіональної ідентичності, ідеологічна робота як механізм формування регіональної ідентичності, образи, символіка, міфологеми, ідеологеми і комунікаційні слогани як механізми формування регіональної ідентичності та ряд інших.

Структура регіональної ідентичності складається із двох компонентів, таких як культурно-ціннісний та стратегічний. Культурний рівень пов'язаний із характеристикою сталих рис регіональної унікальності, ціннісних особливостей співтовариства. Поява стратегічного рівня має на увазі свідоме використання цих особливостей у практичних цілях, наприклад, для підвищення уваги до регіону, мобілізації співтовариства. Це свідомий винахід і використання регіональної унікальності (символічна політика, «винахід традицій», політика ідентичності), а також просування конструйованої унікальності, що виражається у формуванні регіонального образу [9, с. 23].

У ролі носіїв регіональної ідентичності виступають регіональні спільноти. Регіональні спільноти сучасності розглядаються як продукт цілеспрямованого інтелектуального розвитку елітарних груп, основною метою якої є фундація нових типів і форм ідентичностей, що забезпечують успішну групову й індивідуальну соціально-психологічну адаптацію, а також необхідні умови для колективної солідарної дії в політиці. Процес (ре)конструкції ідентичності регіональної спільноти на сучасному етапі досить часто супроводжується навмисним створенням симулякрів, які істотно змінюють сприйняття дійсності рядовими представниками колективу [13, с. 463].

Іншим рівнем ідентичності виступає міська ідентичність. Розглянемо, яким чином проходить процес формування та актуалізації даного виду локальної ідентичності. Міська ідентичність складається в ході символічного виробництва міських смислів, вона сконструйована з репертуару тих значень, з якими стикається людина. Тому ми уявляємо місто як певну сукупність образів людей, вулиць, дерев, звуків, смаків, подій через відбиток цього репертуару значень, через візуальні і вербальні сліди їх репрезентації. Згідно 3 
Б. Андерсоном [1], ми уявляємо будь-яку спільноту, в якій немає прямих контактів, за допомогою уявлень про дане співтовариство. Ці уявлення складаються в процесі комунікації, а саме це участь у святковому заході, зустрічі з городянами, читання публікації про історію вулиці, перегляд фотографій міста в соціальних мережах тощо. Особлива роль належить тим із них, які мають автентичність: унікальні люди, традиції, міфи, завдяки яким відбувається ототожнення з містом.

Н. Федотова у своїй праці «Формування міської ідентичності: факторний і інституціональний аспекти" [12] стверджує, що ідентичність міста завжди автентична, тому міста прагнуть знайти i підкреслити свою винятковість через актуалізацію автентичності, тобто через імідж, бренд або впізнаваний образ, що дозволяє викликати позитивні аспекти у сприйнятті свого (або відвідуваного) міста.

Спостерігається тяжіння колективної свідомості сучасних міст до більш стійких і виразних для зовнішнього і внутрішнього сприйняття урбаністичних образів, що впливає на формування сприятливих вражень від міста і тим самим привертає соціальні, економічні та інші види ресурсів. Перш за все, як показують багато досліджень, прив'язаність до міста забезпечує сам міський простір, 3 яким щодня стикається мешканець міста (мости, річки, кафе, люди). Дослідження візуальної середовища міста іноді зосереджені в рамках концепції «genius loci», де геній (або дух) місця, якщо слідувати феноменології архітектурних особливостей міста, «дозволяє людині ідентифікувати себе 3 середовищем». У цьому випадку місто викликає в нас позитивні емоції, з'являється бажання жити в цьому місці, оскільки ми відчуваємо зв'язок з ним [12, с. $32-49]$.

У своїй роботі «Теоретичні аспекти міської ідентичності» Н. Дягілева робить висновок про те, що для того, щоб визначити дефініцію «міська ідентичність», необхідно врахувати такі моменти:

1) міська ідентичність є соціальною (колективною) ідентичністю та пов'язана із включеністю в довготривалі стабільні соціальні групи, визначає емоційне наповнення самовизначення індивіда по відношенню до такої групи в цілому, до групового імені, до «своїх» i «чужих», а також групові цінності, соціальні норми, стереотипи, поведінкові патерни;

2) міська ідентичність є соціокультурним конструктом, формується в результаті соціалізації та адаптації в певному територіальному поселенні і визначається засвоєнням і відтворенням культурних символів, прийнятих норм, традицій, стилю життя жителів даного поселення;

3) міська ідентичність є результатом ідентифікації людини з міською спільнотою як великою соціальною групою, що відрізняється від ряду інших спільнот, які виділяються за ознакою муніципальної власності [3].
У свою чергу, О. Мусієздов щодо феномену міської ідентичності стверджує, що і «еліти», i «маси» відшуковують, створюють, формулюють, виражають певні смисли, пов'язані з місцем/ містом, задля відповіді на питання про власну ідентичність. Водночас можна припустити, що ті й інші роблять це по-різному. Тобто йдеться про те, що міська ідентичність цих груп має відрізнятися за змістом. Різниця між відповідями респондентів-представників різних груп має полягати не стільки у ступені ідентифікації з містом, скільки у способах інтерпретації власного зв'язку з містом. Так, для «справжнього» жителя міста тією чи іншою мірою характерні: емоційна прив'язаність до міста, яка включає гордість за місто та локальний патріотизм; «менталітет» - це поняття не має наукового визначення, але зазвичай означає певний спосіб або особливості мислення, ставлення до чогось, розуміння культурних кодів тощо. Формується внаслідок тривалого життя в місті, переважно в дитинстві; знання про місто, його історію, культурні особливості; «міська культура» як сукупність певних традицій, особливостей поведінки; відчуття відповідальності за місто, яке може проявлятися як наслідок відчуття себе частиною міської спільноти та/або міста як такого (певний простір, інфраструктура тощо) та спричиняти різного роду громадську активність [6].

Регіональна національна ідентичність має коріння в процесах взаємодії, взаємовпливу та часом конфлікту регіональних ідентичностей, котрі утворилися на історичному етапі розвитку, під дією деяких як соціальних, так і економічних, політичних ситуацій, а також були передумовами незвичних геополітичних особливостей України, що і мало вплив на різницю в національному розумінні себе жителями Сходу, Півдня, Центру і Заходу України. Дане розділення сталося через те, що територія України є границею західноєвропейського, східноєвропейського та середземноморського просторів.

Регіональну ідентичність українців варто розглянути через Східний та Західний регіон України.

Історично зумовлені «націоналізація» Заходу та «інтерналізація» Сходу - найбільш впливові й настільки ж різні тенденції - посилили диференціацію в рамках єдиного географічного простору. У сучасній соціологічній науці використання географічної опозиції «Захід-Схід» вказує на комплекс соціально-економічних та політичних відмінностей, які створюють рельєф, «географію» соціокультурного простору.

Регіональний вимір національної ідентичності тісно пов'язаний з особливостями формування регіонального національного складу населення. Із другої половини XVI ст. відбувалося інтенсивне заселення південних і східних окраїн Росії, 
території між Доном і лівими притоками Дніпра і Десни. Південно-Східна Україна і Донбас - історично український регіон, проте цей регіон заселяли і освоювали різні етноси, серед яких українці у XVII ст. становили 73,8\% (на Донеччині $61,3 \%)$, росіяни - $12,2 \%(20,5 \%)$, молдавани і румуни $-6,2 \%(2,5 \%)$, греки - 3,7\% $(7,3 \%)$, вірмени $-2,6 \%(6,1 \%)$, що формувало особливий етнокультурний тип регіону [2, с. 113].

Унаслідок інтенсивного «перемішування» формувався особливий тип регіональної ідентичності, лише мінімальною мірою, на переконання Л. Нагорної, пов'язаний з етнічністю [8, с. 125]. Надалі процес зросійщення набирає значних темпів (прогресує), що витікало з промислового значення регіону.

Згідно з даними карти В. Кубійовича «Переселення на початок XX ст.», у 1890-1930 pp. на Донбас переселилося приблизно 2 млн, здебільшого росіян із центрально-промислового та інших районів Росії, що оселилися по містах і промислових центрах [4, с. 148]. Це, звичайно, привело до змін у національному стані посідання українців Донбасу в бік зменшення. Коли розпочався промисловий бум та урбанізація, українці виявилися неготовими взяти в них участь. Прискорений промисловий розвиток на теренах Донбасу створив потребу в робітничому, промисловому класі. За даними перепису 1897 р., у гірничодобувній та металургійній промисловості Катеринославської губернії працювало $67,8 \%$ росіян. Перебування різних регіонів України в умовах різних можливостей для економічного розвитку суттєво вплинуло на формування особливостей регіональної ідентичності, а також на етнополітичний розвиток цих регіонів у цілому.

Прослідковуються відмінності у світоглядах та менталітеті Сходу та Заходу, а саме в західному світогляді прослідковується індивідуалістичні та матеріалістичні аспекти, у свою чергу, у східному спостерігається пасивно-споглядальні аспекти, які спрямованої на вищі істини.

Регіональні відмінності між західними і східними українцями сформувалися на різній основі, а саме йдеться про індивідуалістичний та колективістській світогляд. Сьогодні для західних українців ідентичність характеризується орієнтацією на державу та служіння ï інтересам. У свою чергу, східні українці характеризується критичним ставленням до влади, що нерідко межує з анархізмом, орієнтацією на самоорганізацію в рамках громади.

Однією $з$ відмінностей регіональної ідентичності між Заходом та Сходом виступає різні релігійні конфесії. На релігійний світогляд вплинули історичні чинники, для Західної України більше характерний католицизм, у свою чергу, для Східної України - православ’я.
Особливістю Східної України виступає виправдання авторитарних методів політичного управління для гарантування порядку та стабільності, для Заходу України характерне виявлення зацікавлення особистості і долучення до вирішення суспільних та громадських проблем. С. Ліпсет наголошує, що «для Східної України притаманне колективне залучення до політичної сфери, а для Заходу України притаманна самоорганізація на основі індивідуалізму, елітизму» [7, с. 36].

Специфіка культури, звичаї, духовні цінності, мова є головними регіональними відмінностями. Вагомим історичним впливом на регіональні відмінності між Західною та Східною Україною характеризується період СРСР, що вплинув на русифікація та зміну релігійної ідентичності [5, с. 16].

Однією з регіональних ідентичностей між Заходом та Сходом виступає мова. Кожний громадянин України повинен знати та розмовляти на своєї рідній, державній мові. Але на Східній Україні переважно прослідковується російська мова, яка $\epsilon$ виявленням історичних чинників русифікації українців внаслідок імперської політики царської Росії та під час радянського періоду.

Історичними чинниками формування регіонального менталітету Західної України виступає вплив Річі Посполитої, Австро-Угорської імперії, які вплинули на регіональні та демократичні традиції.

Специфіка регіонів базується на поєднанні двох цивілізаційних парадигм, які складаються із прагматичності західної та східної слов'янських цивілізацій, що формує специфічне взаємодоповнююче формування, яке впливає на взаєморозвиток культури, нації та релігії. Безпосередньо формуються специфічні умови існування різних етносів, які впливають на мовну, культурну ситуацію в даному регіоні.

Висновки. Отже, висока питома вага регіональних ідентифікацій в Україні визначається як об'єктивною поліфонічністю національного буття, так і тією сегментованістю простору, яка склалася історично. Культурно-політична інтегральність вибудовується на основі систем різного рівня складності, а обставини політичного життя i різноспрямовані геополітичні чинники, групові інтереси еліт неймовірно ускладнюють процес їі формування.

Регіональна ідентичність формувалася під дією відмінних соціальних та історичних, політико-культурних, релігійних, лінгвістичних, психологічних чинників.

У типах ідентичності саме регіональна ідентичність має специфічну роль та місце в дослідженні менталітету, адже вона має зв'язок із певними місцями, які виокремлюють специфічні структури світу, практик тощо. 
Однією $з$ відмінностей регіональної ідентичності між Заходом та Сходом виступає історичний плив на формування регіонального менталітету. На ідентичність Західної України мали вплив Річ Посполита та Австро-Угорська імперія. У свою чергу, на Східну Україну вагомий вплив спостерігався з боку Російської імперії.

Регіональною відмінністю між західними $\mathrm{i}$ східними українцями виступають різні світогляди. Для Заходу притаманний індивідуалістичний світогляд, а для Сходу - колективний світогляд. Для західних українців ідентичність характеризується орієнтацією на державу та служіння її інтересам. У свою чергу, східні українці характеризуються критичним ставленням до влади, що нерідко межує з анархізмом, орієнтацією на самоорганізацію в рамках громади.

Однією 3 відмінностей регіональної ідентичності між Заходом та Сходом виступають різні релігійні конфесії, для Західної України більше характерний католицизм, у свою чергу, для Східної України - православ'я.

\section{Jimepamypa}

1. Андерсон Б. Уявлені спільноти. Міркування щодо походження й поширення націоналізму. Київ : Критика, 2001. 272 c.

2. Дружба і братерство російського та українського народів. Київ : Наук. думка, 1982. Т. 1.480 с.

3. Дягілева Н. Теоретичні аспекти міської ідентичності. 2013. URL: http://elar.urfu.ru/ bitstream/10995/22420/1/geobrand-2013-12.pdf.

4. Енциклопедія українознавства: Загальна частина / за ред. В. Кубійович, З. Кузеля (репринтне відтворення). Київ : Ін-т археографії НАН України, 1994. T. $1.400 \mathrm{c.}$

5. Колесницька Н.М. Політико-культурні чинники брендингу Львівської області : автореферат дис. к. політ. н. Національний педагогічний університет імені М.П. Драгоманова. Київ : [б.в.], 2015. 16 с.

6. Мусієздов О. Міська ідентичність у (пост)сучасному українському місті (приклад Харкова та Львова). Соціологія: теорія, методи, маркетинг, 2016. № 3. C. 94-111.

7. Нагорна Л. Політична культура українського народу: історична ретроспектива і сучасні реалії. Київ : Стилос, 1998. $136 \mathrm{c.}$

8. Нагорна Л. Регіональна ідентичність : український контекст. Київ : Стилос, 2008. 335 с.

9. Назукина М. Винахід традицій як механізм конструювання національної ідентичності. Інформаційний бюлетень Національного Інституту розвитку сучасної ідеологї̈, 2007. С. 22-25.

10. Регіональна ідентичність: український контекст. Київ : ІПіЕНД імені І.Ф. Кураса НАН України, 2008. 405 c.

11. Рогатин В. Регіон держави як уявна спільнота: до питання про формування регіональної ідентичності. Грані. 2005. 3(41). С. 132-136.
12. Федотова Н. Формування міської ідентичності: факторний і інституціональний аспекти. Журнал соціології та соціальної антропологї̈. 2017. 20(3). С. 32-49.

13. Хорошилов О. Регіональні спільноти як суб'єкти інтеграційних процесів. Вісник Одеського нац. ун-ту. Соціологія і політичні науки. 2009. С. 459-466.

14. Яцик I.C. Філософсько-культурологічна трансформація категорії «ситуація» (Н. Аббаньяно, К. Ясперс). Культурологічна думка. 2011. № 4. С. 223-228.

\section{Анотація}

Шеховиова-Бурянова В. А. Особливості регіональної ідентичності українців. - Стаття.

У статті розглядаються особливості української регіональної ідентичності. Регіональна ідентичність має коріння в процесах взаємодії, взаємовпливу та часом конфлікту регіональних ідентичностей, котрі утворилися на історичному етапі розвитку, під дією деяких як соціальних, так і економічних, політичних ситуацій, а також були передумовами незвичних геополітичних особливостей України, що і мало вплив на різницю в національному розумінні себе жителями Сходу, Півдня, Центру і Заходу України. Дане розділення сталося через те, що територія України є границею західноєвропейського, східноєвропейського та середземноморського просторів. Регіональний вимір національної ідентичності тісно пов'язаний з особливостями формування регіонального національного складу населення. Однією з регіональних ідентичностей між Заходом та Сходом виступає мова. Вагомим історичним впливом на регіональні відмінності між Західною та Східною Україною характеризується період СРСР, що вплинув на русифікацію та зміну релігійної ідентичності.

Відмінністю Західної від Східної Україна виступає вплив східної і західної культури на формування регіонального менталітету. Регіональні відмінності між західними і східними українцями сформувалися на різній основі, а саме йдеться про індивідуалістичний та колективістській світогляд. Сьогодні для західних українців ідентичність характеризується орієнтацією на державу та служіння іï інтересам. У свою чергу, східні українці характеризується критичним ставленням до влади, що нерідко межує з анархізмом, орієнтацією на самоорганізацію в рамках громади.

Однією з відмінностей у регіональній ідентичності Заходу та Сходу є різні релігійні конфесії. На релігійний світогляд вплинули історичні фактори, для Західної України більше притаманний католицизм, у свою чергу, Східна Україна - більш православна.

Відмінністю регіональною ідентичністю між Заходом та Сходом виступає мова. На Західній Україні переважає українська мова. Але на Східній Україні переважно прослідковується російська мова, яка $€$ виявленням таких історичних чинників: русифікації українців, імперської політики царської Росії та політики влади радянського періоду.

Ключові слова: ідентичність, нація, національна ідентичність, регіональна ідентичність, міська ідентичність, ментальність, націоналізація, інтерналізація. 


\section{Summary}

Shekhovtsova-Burianova $V$. A. Features of the regional identity of Ukrainians. - Article.

The article considers the peculiarities of the Ukrainian regional identity. Regional identity has its roots in the processes of interaction, interaction and sometimes conflict of regional identities, which were formed at the historical stage of development, under the influence of some social and economic, political situations, and were prerequisites for unusual geopolitical features of Ukraine in the national sense, residents of the East, South, Center and West of Ukraine. This division is due to the fact that the territory of Ukraine is foreign to Western Europe, Eastern Europe and the Mediterranean. The regional dimension of national identity is closely related to the peculiarities of the formation of the regional national composition of the population. One of the regional identities between West and East is language. The period of the USSR, which influenced the Russification and change of religious identity, has a significant historical influence on regional differences between Western and Eastern Ukraine. The difference between Western and Eastern Ukraine is the influence of Eastern and Western culture on the formation of a regional mentality.
Regional differences between Western and Eastern Ukrainians were formed on different grounds, namely the individualistic and collectivist worldview. Today, for Western Ukrainians, identity is characterized by a focus on the state and serving its interests. In turn, Eastern Ukrainians are characterized by a critical attitude to power, which often borders on anarchism, the focus on self-organization within the community.

One of the differences in regional identity between West and East is the different religious denominations. The religious worldview was influenced by historical factors, Western Ukraine is more characterized by Catholicism, in turn, Eastern Ukraine is more Orthodox.

Regional communities act as carriers of regional identity. Modern regional communities are seen as a product of purposeful intellectual engineering of elite groups, the main purpose of which is the foundation of new types and forms of identities that ensure successful group and individual socio-psychological adaptation, as well as the necessary conditions for collective solidarity in politics.

Key words: identity, nation, national identity, regional identity, urban identity, mentality, nationalization, internalization. 